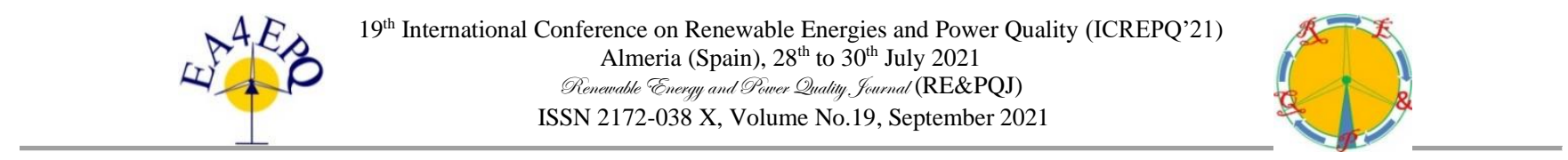

\title{
Impact on the Spanish electricity network due to the massive incorporation of electric vehicles
}

\author{
Francisco M. Arrabal-Campos ${ }^{1}$, Juan Martínez-Lao ${ }^{1}$, Francisco G. Montoya ${ }^{1}$, Alfredo Alcayde ${ }^{1}$ and \\ Raúl Baños ${ }^{1}$ \\ ${ }^{1}$ Department of Engineering \\ E.S.I., University of Almeria \\ Carretera de Sacramento s/n - La Cañada, 04120 Almería (Spain) \\ Phone/Fax number:+34950214501,e-mail: fmarrabal@ual.es, pagilm@ual.es, aalcayde@ual.es, rbanos@ual.es, \\ jm1357@ual.es
}

\begin{abstract}
Electric vehicles, along with renewable energy, are two of the most important components for achieving a more sustainable and cleaner future. This paper study the Spanish electricity demand at the Iberian Peninsula level during the eleven-year period 2007-2018 with daily data from the Spanish electricity network, calculating the monthly daily average for each year as actual data on the use of the electricity distribution network. Having in mind this information, the number of electric vehicles (EVs) that could be charged in Spain is being studied in order to reorganize the Spanish production system. Three different scenarios are analyzed (slow, accelerated and fast charging) according to the capacity conditions of the electric distribution network, previously determining the available electric energy that varies according to the electric demand. Results obtained reveals the need of a complex reorganization of the Spanish electricity production system due to the geographical seasonality of electricity demand.
\end{abstract}

Key words. Electric Vehicles, Climate Policy, Renewable Energy, Transport Sector, Electricity Network.

\section{Introduction}

The environmental concerns caused by fossil fuel vehicles, along with the advances in battery technology and their manufacturing processes have promoted a transition towards electric vehicles (EVs). At the end of 2018, the 665,000 electric vehicle units represented 0.08\% of the total number of passenger cars worldwide [1]; by the same year, the European Union market reached 75,331 electric vehicles sold, of which 1405 were in Spain [2]. The International Energy Agency estimates that $80 \%$ of the cars sold in 2050 will be electric [3]. In addition, worldwide sales of electric vehicles will increase from the current 1.1 million to 11 million in 2025 , and 30 million in 2030. China will lead this transition with $50 \%$ of the global EV market by 2025 [4,5].

The demand for Spanish electricity increased from 2014 to 2018 [6], reaching close to the level recorded in the mid-2000s, indicating that the economic recession that began with the crisis in 2008 had been overcome at 2018 [6]. It is also observed that the rate of increase in demand by more than one point and is due to the decline in the export balance of international trade compared to the previous year.

As regards maximum demand, maximum instantaneous power reached 41,277 MW on February 8, 2018 [7]. On the same day the maximum demand was 40,947 MW. This demand is still far from the Spanish record of December 17, 2007, when the peak demand reached 44,876 MW, reached between 7.00 and 8.00 p.m [7]. Nevertheless, the COVID-19 pandemic has provoked a severe global economic crisis which has caused a recession in some nations, including Spain [8], which GDP has decreased remarkably in 2020 and is also notable at the beginning of 2021. This has involved again a significant reduction of the demand of electricity.

In addition to the total demand of electricity in Spain, it is also interesting to define the structure of electricity generation, which has been very different according to the type of technology [9]. Thus, combined cycles with coal recorded significant decreases compared to the previous year and renewables rose significantly favored by increasing generation from PV solar and wind energy systems. It is important to indicate that extra loads created by the increasing number of electric vehicles may have adverse impacts on grid $[10,11]$.

The paper is organized as follows. First, it is introduced and explained the methodology used. Second, three electric vehicles charging scenarios are analyzed. Afterward, it is done an analysis of recharging in accordance with the vehicle fleet. Finally, a conclusion is drawn on the difficulties that may arise in the implementation of the electric vehicle. Herein, we analyze the number of electric vehicles (EVs) that could be charged in Spain in three different scenarios (slow, accelerated and fast charging) according to the capacity conditions of the electric distribution network using data collected between 2007-2018.

\section{Methods}

The first step to analyze the problem at hand is to obtaining data of the Spanish electricity network. This 
process, summarized in Figure 1, establishes three recharging scenarios (slow, fast and accelerated charge) [12]. The analyzed parameters were electric power available, average monthly demand and daily availability.

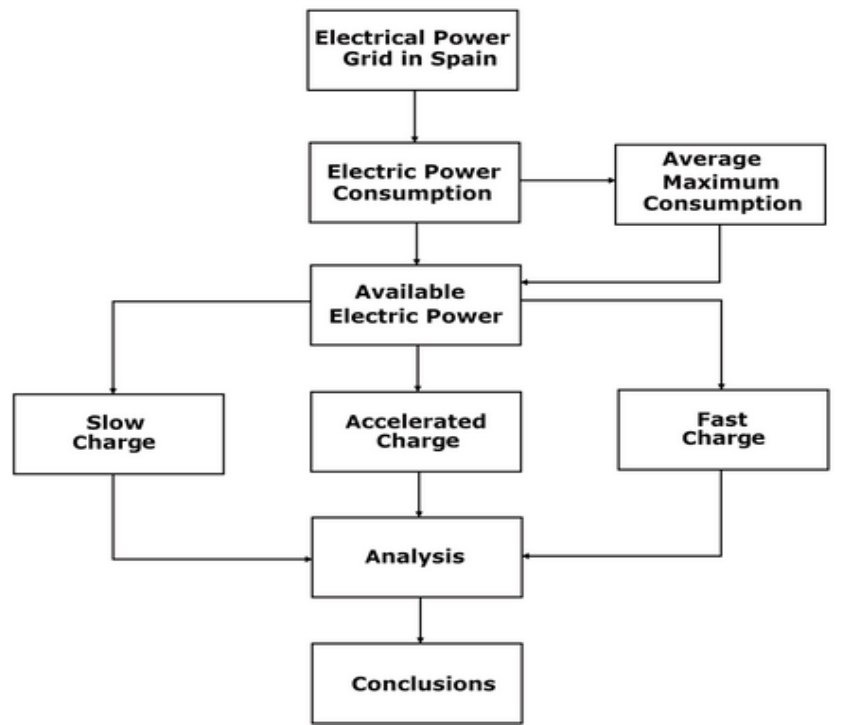

Fig. 1. Framework of the investigation.

Having in mind that the aim here is to determine the number of electric vehicles that could be charged in Spain under the current conditions of distribution grid capacity, the available electrical energy is determined, which varies according to the electrical demand. The study of the Spanish electricity demand at the peninsular level is carried out for the period 2007-2018 (11 years), the latter included. The data have been obtained from the REE (2018) [7]. The data accessible on the grid are daily and from them a monthly daily average is made for each year as real data on the use of the electric power distribution grid.

It is now known that during night-time hours the demand for electricity drops considerably, that happened because the power plants are programmed, and outages occur during these low demand hours. The available electrical energy can then be defined as the "spare" energy capacity during the hours of low demand, the so-called "off-peak" hours, if the power plants operate constantly throughout the day.

In order to obtain de maximum power available for battery charging, it is necessary to calculate this availability of electric power. Then, the calculation yields Equation (1).

$P_{a}=\max \left(P_{d}\right)-P_{d}$

The electricity demand is shown in Figure 2 for the time interval studied. This figure corresponds to the average daily demand during the month of February from 2007 to 2018. The maximum daily average is $37,422 \mathrm{MW}$ and corresponds to the $21: 10$ hours $(9.10$ p.m. $)$ reading. This real demand data means that the electricity system during this month has been able to cover this maximum daily demand. It is possible to see how the demand for electricity varies greatly throughout the day, forming the so-called "valleys", which occur during off-peak hours, especially during the night hours from 23:00 to 07:00 (11:00 p.m. to 07:00 a.m.).

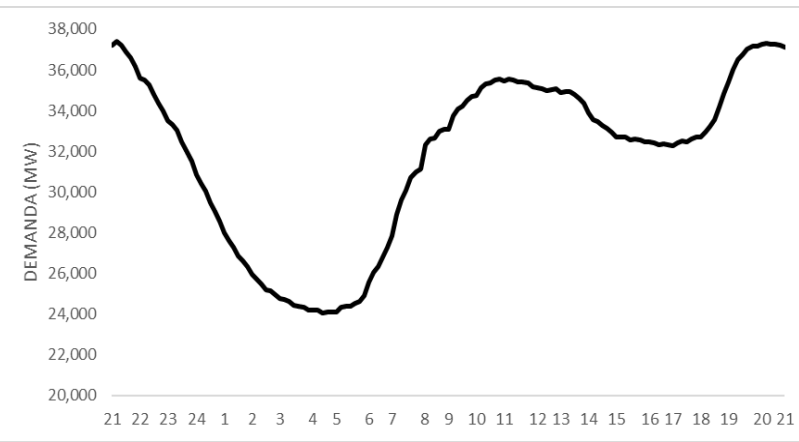

Fig. 2. Average daily electricity demand for February for the period 2007-2018.

The electric system can withstand a demand higher than the maximum daily demand that it is required to meet, since it is prepared if a greater demand for electric energy is required. The installed power is much higher than the demand, as Table 1 shows.

As example, it is calculated the availability of electric power is shown in Figure 3 applying the Equation (1) for the time interval. This figure shows the average daily demand during the month of February from 2007 to 2018.

Table 1. Maximum monthly average daily demand in the period 2007-2018.

\begin{tabular}{|c|c|}
\hline SOURCE & TOTAL POWER \\
\hline Hydraulic & 17786 \\
\hline Nuclear & 7866 \\
\hline Coal & 11641 \\
\hline Oil/Gas & 3498 \\
\hline Combined cycle & 27206 \\
\hline Total ordinary regime & 67998 \\
\hline Hydraulic & 2102 \\
\hline Wind & 23010 \\
\hline Photovoltaic & 4665 \\
\hline Thermoelectric & 2300 \\
\hline Renewable thermal & 980 \\
\hline Non-renewable thermal & 7210 \\
\hline Total special regime & $\mathbf{4 0 2 6 7}$ \\
\hline TOTAL & $\mathbf{1 0 8 2 6 5}$ \\
\hline
\end{tabular}

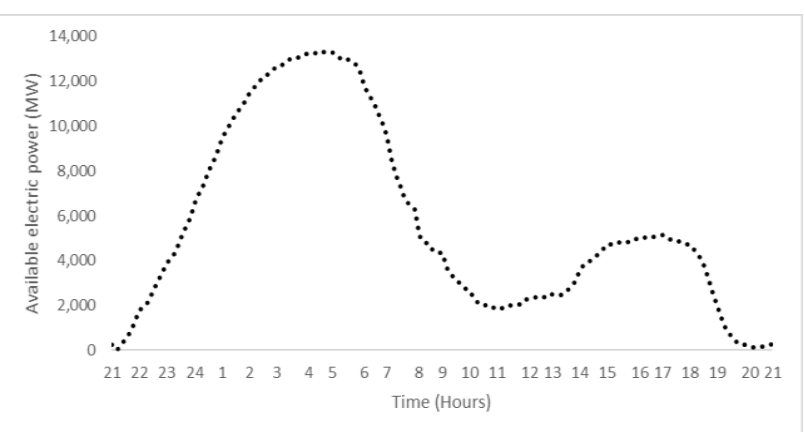

Fig. 3. Average daily average electrical availability for February for the period 2007-2018.

The hypothesis is based on the maximum monthly demand, that is the energy system can cover a maximum demand for each time interval. As example, in February the maximum monthly demand is $37,422 \mathrm{MW}$, in this case, it would also be able to cover this maximum demand throughout the day continuously during that month. For all months of the year is shown in the Table 2 . 
Table 2. Maximum monthly average daily demand in the period 2007-2018.

\begin{tabular}{|c|c|c|}
\hline & $\begin{array}{c}\text { MAXIMUM } \\
\text { AVERAGE } \\
\text { DAILY } \\
\text { DEMAND (MW) }\end{array}$ & $\begin{array}{c}\text { DIFFERENCE IN } \\
\text { CONSUMPTION WITH } \\
\text { RESPECT TO THE } \\
\text { HIGHEST MONTH (MW) }\end{array}$ \\
\hline January & 37253 & 169 \\
\hline February & 37422 & 0 \\
\hline March & 34957 & 2465 \\
\hline April & 32407 & 5015 \\
\hline May & 31341 & 6081 \\
\hline June & 33027 & 4395 \\
\hline July & 35131 & 2291 \\
\hline August & 33116 & 4306 \\
\hline September & 33276 & 4146 \\
\hline October & 32707 & 4715 \\
\hline November & 34926 & 2496 \\
\hline December & 35901 & 1521 \\
\hline
\end{tabular}

The monthly analysis has been considered to adapt to the generation of the Spanish electricity system and its interaction with the distribution grid. However, the average daily value of maximum demand obtained in February is the maximum proven operating capacity of the distribution grid and can be taken as a reference to calculate the minimum number of electric vehicles that could be charged throughout the year, since in the rest of the months we would have guaranteed the recharging of electric vehicles as the average daily demand is lower.

\section{A. Prior considerations}

The average recharging of an electric vehicle depends on the type of vehicle, as it is shown in Figure 5, where they are included, the main electric vehicles sold in the Spanish market in 2018 and the capacity of their batteries. All of them are batteries based on lithium-ion technology. The battery capacity data of the different electric vehicles in the Spanish market varies between $14.5 \mathrm{kWh}$ and $24 \mathrm{kWh}$. To carry out the analysis, it is considered a $19 \mathrm{kWh}$ battery, which is the average of the batteries analyzed.

\section{B. Recharge scenarios and method of analysis.}

The analysis of the availability of recharging in the Spanish electricity system will be carried out based on the electricity demand data collected.

Table 3 shows the three recharging scenarios considered. The method used for the analysis of each recharge scenario was as follows:

1) It is identified on the electrical availability data collected in the hourly intervals where we have energy available for use in EV charging throughout the day and night.

2) The hourly interval of electrical availability selected is divided according to the time required for a $100 \%$ recharge of the EV battery depending on the recharge scenario under analysis.

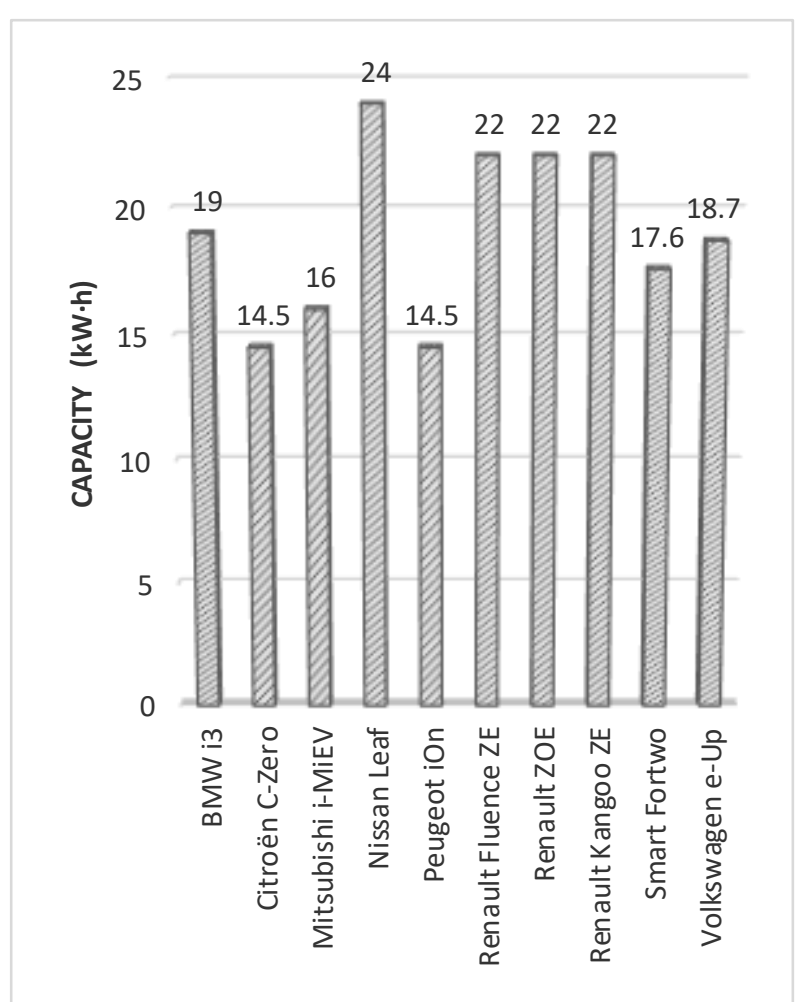

Fig 5. Battery capacity of Electric Vehicles (kWh).

Table 3. Power range of recharge scenarios.

\begin{tabular}{|l|c|c|c|}
\hline & $\begin{array}{c}\text { SLOW } \\
\text { RECHARGE } \\
\text { SCENARIO }\end{array}$ & $\begin{array}{c}\text { ACCELERATED } \\
\text { RECHARGE } \\
\text { SCENARIO }\end{array}$ & $\begin{array}{c}\text { FAST } \\
\text { RECHARGE } \\
\text { SCENARIO }\end{array}$ \\
\hline $\begin{array}{l}\text { Power } \\
\text { range of } \\
\text { the } \\
\text { recharging } \\
\text { installation }\end{array}$ & $3-3.7 \mathrm{~kW}$ & $7-43 \mathrm{~kW}$ & $30-250 \mathrm{~kW}$ \\
\hline $\begin{array}{l}\text { Connection } \\
\text { type }\end{array}$ & $1 \mathrm{p}-\mathrm{AC}$ & $3 \mathrm{p}-\mathrm{AC}$ & $\mathrm{DC}$ \\
\hline
\end{tabular}

The EV recharging time varies directly according to the power supplied to the EV and according to the EV battery capacity. It is obtained using the equation 2. The energy capacity of the battery (C) is $19 \mathrm{kWh}$ for the 3 recharge scenarios.

$$
P=\frac{C}{t}
$$

where $\mathrm{P}$ is the $\mathrm{EV}$ charging power $(\mathrm{kW}), \mathrm{C}$ is the capacity $(\mathrm{kWh})$ and $\mathrm{t}$ is time (hours).

3) The most unfavorable electrical availability data for the segments is chosen, and with this data the number of EVs that could be recharged in that time interval is calculated. This minimum value limits the electrical availability for each of the segments. This ensures constant availability for each section from the worst-case segment.

4) The number of electric vehicles that can be $100 \%$ recharged is calculated based on the available energy (worst-case value) in the studied time period. 


\section{Slow recharge scenario}

In this case, the study focuses on slow recharging at 3-3.7 $\mathrm{kW}, 16 \mathrm{~A}$ and $230 \mathrm{~V}$ in single-phase alternating current. The time required to recharge the battery of an EV up $100 \%$ is calculated with the Equation (2). The capacity base is $19 \mathrm{kWh}$. This yield approximately 6 hours as recharging time.

Table 4. Number of EVs that can recharge in the slow recharge scenario.

\begin{tabular}{|c|c|c|c|r|r|l|}
\hline & $\mathbf{1 - 7}$ H & $\mathbf{7 - 1 3}$ H & $\mathbf{1 3 - 1 9}$ H & $\mathbf{1 5 - 2 1}$ H & $\mathbf{1 8 - 2 4}$ H & TOT.EV \\
\hline January & 2474594 & 498645 & 165405 & - & - & 3138644 \\
\hline February & 2553513 & 508108 & 546216 & - & - & 3607837 \\
\hline March & 2348918 & 520270 & 591621 & - & - & 3460810 \\
\hline April & 2072432 & 331351 & 363513 & - & - & 2767297 \\
\hline May & 1941351 & - & - & 538919 & - & 2480270 \\
\hline June & 2082702 & - & - & - & 500270 & 2582972 \\
\hline July & 2204864 & - & - & - & 561351 & 2766215 \\
\hline August & 1969189 & - & - & 331622 & - & 2300811 \\
\hline September & 2150540 & 180541 & 172162 & - & - & 2503243 \\
\hline October & 2165675 & 424865 & 439189 & - & - & 3029729 \\
\hline November & 2457027 & 635135 & - & - & - & 3092162 \\
\hline December & 2461621 & 624324 & - & - & - & 3085945 \\
\hline
\end{tabular}

The ideal place for this type of recharging is in the home itself due to its long waiting time and that the required power of $3.7 \mathrm{~kW}$ at $16 \mathrm{~A}$ can be provided by the electrical system of a regular house in Spain [13]. All the 6-hour time slots throughout a day ( 24 hours) in which electricity is available are identified. These intervals will change depending on the month being analyzed.

From the available energy, it is calculated the number of vehicles that can be recharged in each hourly interval under the proposed slow recharging conditions, see Table 4. The calculation is done by dividing the available energy by the power of the connection, such that the result obtained gives the number of vehicles that could be recharged each day during each month of the year. Results displayed in Table 4 shown the total number of EVs that can be recharged throughout the day under the conditions assumed in this slow recharging scenario with 6-hour hourly intervals, where the most unfavourable month would be August with 2,300,811 vehicles and the most favourable month would be February with 3,607,837 vehicles.

\section{Accelerated recharge scenario}

For the accelerated recharging scenario, it is assumed that recharging is performed at $11 \mathrm{~kW}, 32 \mathrm{~A}$ and $400 \mathrm{~V}$ threephase AC current. The battery capacity is the average of the vehicles studied and is $19 \mathrm{kWh}$. The time required to charge the battery of an EV to $100 \%$ under these conditions is 2 hours. The ideal place for this type of recharging are city centers, supermarkets, shopping malls and leisure center. This type of recharging is more related to daytime recharging since these establishments are more used during the day. Recharging will be analysed throughout the day to contemplate all the energy available, following the method described in previous sections. For each 2-hour interval, the number of EVs that can be recharged is calculated according to the most unfavorable availability data (MW) of the interval. In this way, constant availability is achieved during each 2-hour interval (time required to recharge $100 \%$ of the EV battery), 24 hours a day.

In the Table 5, it is shown the available electrical energy values calculated on the average values in 2-hour time intervals from 0 to 12 hours from the monthly average daily electrical availability curves, and Table 6 shows the average values from 12 to 24 hours of each day.

Table 7 summarizes the total number of EVs that could be recharged in a staggered manner in 2-hour intervals in the accelerated recharging scenario in each month of the year. Under this charging scenario, the most unfavorable month is May with a recharging possibility of 3,424,727 vehicles. The most favorable month is February with $4,920,727$, and it is relevant that it coincides with the month of maximum average daily electricity demand.

Table 5. Number of EVs that can recharge in the 0-12 hour accelerated recharge scenario.

\begin{tabular}{|c|c|c|c|c|c|c|}
\hline & $\mathbf{0 - 2}$ H & $\mathbf{2 - 4} \mathbf{H}$ & $\mathbf{4 - 6 ~ H}$ & $\mathbf{6 - 8} \mathbf{H}$ & $\mathbf{8 - 1 0} \mathbf{H}$ & $\mathbf{1 0 - 1 2} \mathbf{~}$ \\
\hline January & 575273 & 1023000 & 1139000 & 594091 & 262636 & 167727 \\
\hline February & 598091 & 1043727 & 1138545 & 571182 & 242000 & 170909 \\
\hline March & 562364 & 957545 & 1036455 & 621455 & 248727 & 175000 \\
\hline April & 510455 & 852455 & 937818 & 568818 & 220818 & 124182 \\
\hline May & 470909 & 792273 & 849818 & 532636 & 158455 & 31273 \\
\hline June & 521818 & 846909 & 923818 & 629455 & 214545 & 54727 \\
\hline July & 558636 & 906909 & 1017818 & 743636 & 271909 & 79182 \\
\hline August & 475000 & 818091 & 936364 & 716091 & 301182 & 91727 \\
\hline September & 599455 & 895091 & 943091 & 567545 & 262091 & 104273 \\
\hline October & 653182 & 944000 & 970182 & 474727 & 261364 & 172727 \\
\hline November & 657727 & 1035909 & 1079091 & 591273 & 282636 & 213636 \\
\hline $\begin{array}{c}\text { December } \\
\text { A } 558000\end{array}$ & 1019455 & 1140182 & 640364 & 293455 & 210000 \\
\hline
\end{tabular}

Table 6. Number of EVs that can recharge in the 12- to 24-hour accelerated recharge scenario.

\begin{tabular}{|c|c|c|c|c|c|c|}
\hline & $\mathbf{1 2 - 1 4}$ H & $\mathbf{1 4 - 1 6}$ H & $\mathbf{1 6 - 1 8} \mathbf{H}$ & $\mathbf{1 8 - 2 0}$ H & $\mathbf{2 0 - 2 2} \mathbf{H}$ & $\mathbf{2 2 - 2 4} \mathbf{~ H}$ \\
\hline January & 189818 & 280727 & 287636 & 19727 & - & 135091 \\
\hline February & 204182 & 322727 & 428636 & 22091 & 6909 & 171727 \\
\hline March & 190364 & 286818 & 433091 & 77636 & 14727 & 169545 \\
\hline April & 111455 & 201636 & 342455 & 348727 & 3455 & 78091 \\
\hline May & - & 79545 & 208273 & 240818 & 18364 & 42364 \\
\hline June & - & 61636 & 172455 & 193091 & 175818 & 168273 \\
\hline July & - & 49455 & 166818 & 188818 & 231636 & 226727 \\
\hline August & - & 25545 & 156545 & 187727 & 60727 & 88818 \\
\hline September & 57909 & 122909 & 240091 & 233091 & 4818 & 163636 \\
\hline October & 142909 & 230727 & 350636 & 59364 & & 209909 \\
\hline November & 217000 & 309545 & 212364 & & 5273 & 211182 \\
\hline \begin{tabular}{c} 
December \\
\hline
\end{tabular} & 237364 & 314909 & 191273 & 13455 & 17455 & 152000 \\
\hline
\end{tabular}


Table 7. Sum of electric vehicles that can be recharged in the accelerated recharging scenario.

\begin{tabular}{|c|c|}
\hline & TOTAL, EVS \\
\hline January & 4674727 \\
\hline February & 4920727 \\
\hline March & 4773727 \\
\hline April & 4300364 \\
\hline May & 3424727 \\
\hline June & 3962546 \\
\hline July & 4441546 \\
\hline August & 3857818 \\
\hline September & 4194000 \\
\hline October & 4469727 \\
\hline November & 4815636 \\
\hline December & 4787909 \\
\hline
\end{tabular}

\section{Fast recharge scenario}

The case of fast charging is used $40 \mathrm{~kW}$ as power base. The battery remains as calculated and has a capacity of 19 $\mathrm{kWh}$. Thus, the time required to have the battery charged to $100 \%$ is going to be 30 minutes. It will take 30 minutes to fully recharge the battery of an electric vehicle under the above conditions. From the calculated electric power availability data, the number of electric vehicles that could be recharged by fast recharging in 30-minute intervals with a that power connection is determined. Table 8 shows the number of electric vehicles that can be recharged every 30 minutes at hourly intervals ranging from 0 hours to 4 hours for each month of the year. The highest value is found in the month of February in the hourly interval from 3:30 to 4 hours with 260260 vehicles, and the lowest value in the month of May in the hourly interval from 0:00 to 0:30 hours with 103600 vehicles.

Table 8. Total sum of electric vehicles that can be recharged in

\begin{tabular}{|c|c|} 
the fast-charging scenario. \\
\hline TOTAL, EVS \\
\hline January & 4969780 \\
\hline February & 5221640 \\
\hline March & 5059300 \\
\hline April & 4513140 \\
\hline May & 3758580 \\
\hline June & 4169680 \\
\hline July & 4603900 \\
\hline August & 4139860 \\
\hline September & 4387480 \\
\hline October & 4752240 \\
\hline November & 5072680 \\
\hline December & 5118340 \\
\hline
\end{tabular}

Table 8 shows the total number of EVs that could be recharged in a staggered manner in 30-minute intervals in the fast-recharging scenario in each month of the year. The most unfavorable month is May with a recharging possibility of 3758580 vehicles. The most favorable month is February with 5221640, and it is relevant that it coincides with the month of maximum average daily electricity demand. This fact is explained by the fact that although there is peak consumption, in the rest of the hours the average is lower than in the other months and therefore there is more electricity available.

\section{Analysis of recharging in accordance with the vehicle fleet}

To analyze the three proposed recharging scenarios, it is considered, on the one hand, the values of lower energy availability by always assuming the highest demand in the electric grid, and on the other hand, the fact that the hourly recharging periods in the scenario are complete and recharging is not carried out discontinuously. Table 9 shows the number of conventional vehicles in mainland Spain (DGT, 2018).

Table 9. Fuel vehicles fleet in mainland Spain by Autonomous Communities

\begin{tabular}{|l|r|}
\hline \multicolumn{1}{|c|}{ REGION } & Fuel Vehicles 2018 \\
\hline Andalucía & 3.736 .682 \\
\hline Aragón & 567.011 \\
\hline Asturias & 493.570 \\
\hline Cantabria & 287.067 \\
\hline Castilla y León & 1.237 .841 \\
\hline Castilla-La Mancha & 979.861 \\
\hline Cataluña & 3.309 .596 \\
\hline Comunidad Valenciana & 2.356 .007 \\
\hline Extremadura & 544.636 \\
\hline Galicia & 1.451 .890 \\
\hline Madrid, Comunidad de & 3.256 .265 \\
\hline Murcia, Región de & 685.074 \\
\hline Navarra & 299.536 \\
\hline País Vasco & 946.694 \\
\hline Rioja, La & 134.699 \\
\hline & $\mathbf{2 0 . 2 8 6 . 4 2 9}$ \\
\hline
\end{tabular}

Table 10. Electric vehicle fleet that can be replaced by Autonomous Community and by recharging scenario.

\begin{tabular}{|l|l|r|r|r|}
\hline \multicolumn{1}{|c|}{ Region } & $\begin{array}{l}\text { 2018 } \\
\text { Fuel } \\
\text { VEs }\end{array}$ & $\begin{array}{c}\text { Slow } \\
\text { Charge }\end{array}$ & $\begin{array}{l}\text { Acc. } \\
\text { Charge }\end{array}$ & $\begin{array}{c}\text { Fast } \\
\text { Charge }\end{array}$ \\
\hline Andalucia & 3736682 & 423801 & 630822 & 692316 \\
\hline Aragón & 567011 & 64308 & 95722 & 105053 \\
\hline Asturias & 493570 & 55979 & 83324 & 91446 \\
\hline Cantabria & 287067 & 32558 & 48462 & 53187 \\
\hline $\begin{array}{l}\text { Castilla y } \\
\text { León }\end{array}$ & 1237841 & 140391 & 208970 & 229342 \\
\hline Castilla-La & 979861 & 111132 & 165419 & 181544 \\
\hline
\end{tabular}




\begin{tabular}{|l|r|r|r|r|}
\hline Mancha & & & & \\
\hline Cataluña & 3309596 & 375362 & 558722 & 613187 \\
\hline $\begin{array}{l}\text { Comunidad } \\
\text { Valenciana }\end{array}$ & 2356007 & 267209 & 397738 & 436511 \\
\hline Extremadura & 544636 & 61771 & 91945 & 100908 \\
\hline Galicia & 1451890 & 164668 & 245106 & 269000 \\
\hline $\begin{array}{l}\text { Madrid, } \\
\text { Comunidad } \\
\text { de }\end{array}$ & 3256265 & 369313 & 549718 & 603306 \\
\hline $\begin{array}{l}\text { Murcia, } \\
\text { Región de }\end{array}$ & 685074 & 77698 & 115653 & 126927 \\
\hline Navarra & 299536 & 33972 & 50567 & 55497 \\
\hline País Vasco & 946694 & 107370 & 159819 & 175399 \\
\hline Rioja, La & 134699 & 15277 & 22740 & 24956 \\
\hline TOTAL VE & $\mathbf{2 0 2 8 6 4 2 9}$ & $\mathbf{2 3 0 0 8 1 1}$ & $\mathbf{3 4 2 4 7 2 7}$ & $\mathbf{3 7 5 8 5 8 0}$ \\
\hline $\begin{array}{l}\text { \% Charging } \\
\text { scenario }\end{array}$ & $\mathbf{1 0 0 , 0}$ & $\mathbf{1 1 , 3}$ & $\mathbf{1 6 , 9}$ & $\mathbf{1 8 , 5}$ \\
\hline
\end{tabular}

The percentage of vehicles that can be replaced in each of the recharging scenarios considered is $11.3 \%$ of the existing vehicle fleet for slow recharging, $16.9 \%$ for accelerated recharging and $18.5 \%$ for fast recharging, see table 10.

\section{Conclusion}

The implementation of electric vehicles reveals a complex reorganization of the Spanish electricity production system due to the geographical seasonality of electricity demand Therefore, the easiest way to implement EV on a massive scale in Spain is by means of slow recharging according to the average monthly energy available, based on the average monthly demand With this scenario, recharging is carried out in 6-hour hourly intervals, reaching up to $11.3 \%$ replacement of conventional vehicles by electric vehicles However, a maximum replacement of $18.5 \%$ of the conventional vehicle fleet could be reached with the rapid recharge scenario, although in this case, a process that should be legislated with greater definition should be considered in the area of recharge infrastructure, recharge management systems and production system management. The analysis of each of the recharging scenarios leads us to a maximum replacement capacity of $18.5 \%$ of the current vehicle fleet, which limits the approach of planning a massive introduction of electric vehicles. The large-scale deployment of electric vehicles would require a reorganization of the electric power generation system on the one hand, and the distribution network on the other.

\section{Acknowledgement}

This work was supported by project PGC2018-098813- BC33 (Spanish "Ministerio de Ciencia, Innovación y Universidades"), and by European Regional Development Funds (ERDF)

\section{References}

[1] Cama-Pinto, D., Martínez-Lao, J. A., Solano-Escorcia, A. F., \& Cama-Pinto, A. (2020). Forecasted datasets of electric vehicle consumption on the electricity grid of Spain. Data in Brief, 31, 105823.

[2] Europena Enviroment Agency. Available: https://www.eea.europa.eu/data-andmaps/indicators/proportion-of-vehicle-fleet-meeting5/assessment [Accessed: March, 20th, 2021].

[3] Internation Energy Agency. Available: https://www.iea.org/reports/global-ev-outlook-2020 [Accessed: March, 20th, 2021].

[4] Alfaro-Algaba, M., \& Ramirez, F. J. (2020). Technoeconomic and environmental disassembly planning of lithium-ion electric vehicle battery packs for remanufacturing. Resources, Conservation and Recycling, 154(August 2019), 104461.

[5] Colmenar-Santos, A., Muñoz-Gómez, A. M., RosalesAsensio, E., \& López-Rey, Á. (2019). Electric vehicle charging strategy to support renewable energy sources in Europe 2050 low-carbon scenario. Energy, 183, 61-74.

[6] REE. Catálogo de publicaciones. Available: https://www.ree.es/es/datos/publicaciones [Accessed: March, 20th, 2021].

[7] REE. Spanish Peninsula Electricity demand tracking in real time. Available:

https://demanda.ree.es/visiona/peninsula/demanda/acumulad a/2021-03-20 [Accessed: March, 20th, 2021].

[8] Nergaard, D. K. (2005). The electric vehicle, technology and expectations in the automobile age - Book Review. IEEE Technology and Society Magazine, 24(1), 55-56.

[9] Sánchez de la Nieta, A. A., \& Contreras, J. (2020). Quantifying the effect of renewable generation on day-ahead electricity market prices: The Spanish case. Energy Economics, 90.

[10] Hu, J., Morais, H., Sousa, T., Lind, M. Electric vehicle fleet management in smart grids: A review of services, optimization and control aspects. Renewable and Sustainable Energy Reviews (2016). Vol. 56, pp. 1207-1226.

[11] Hussain, M.T., Sulaiman, N. B., Hussain, M.S., Jabir, M. Optimal Management strategies to solve issues of grid having Electric Vehicles (EV): A review. Journal of Energy Storage (2021), Vol. 33, 102114.

[12] Martínez-Lao, J., Montoya, F.G., Montoya, M.G., Manzano-Agugliaro, F. Electric vehicles in Spain: An overview of charging systems. Renewable and Sustainable Energy Reviews (2017), Vol. 77, pp. 970-983.

[13] Reglamento Electrotécnico de Baja Tensión (REBT). Available: https://www.boe.es/buscar/doc.php?id=BOE-A2002-18099 [Accessed: March, 20th, 2021]. 